Rough and Tumble 
This page intentionally left blank 


\section{Rough and Tumble}

Aggression, Hunting,

and Human Evolution

\section{Travis Rayne Pickering}

甲

UNIVERSITY OF CALIFORNIA PRESS

Berkeley · Los Angeles • London 
University of California Press, one of the most distinguished university presses in the United States, enriches lives around the world by advancing scholarship in the humanities, social sciences, and natural sciences. Its activities are supported by the UC Press Foundation and by philanthropic contributions from individuals and institutions. For more information, visit www.ucpress.edu.

University of California Press

Berkeley and Los Angeles, California

University of California Press, Ltd.

London, England

(C) 2013 by The Regents of the University of California

Library of Congress Cataloging-in-Publication Data

Pickering, Travis Rayne.

Rough and tumble : aggression, hunting, and human evolution / Travis Rayne Pickering.

p. $\mathrm{cm}$.

Includes bibliographical references and index.

ISBN 978-0-520-27400-6 (cloth : alk. paper)

I. Hunting, Prehistoric. 2. Hunting and gathering societies. 3. Fossil hominids. 4. Human evolution.

5. Social evolution. I. Title.

$\mathrm{GN}_{799} \mathrm{H}_{4} \mathrm{P}_{53} 2 \mathrm{OI} 3$

$599 \cdot 9--\mathrm{dc} 23$

2012027494

Manufactured in the United States of America

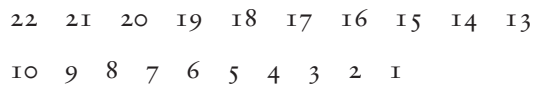

In keeping with a commitment to support environmentally responsible and sustainable printing practices, UC Press has printed this book on Rolland Enviroroo, a Io०\% post-consumer fiber paper that is FSC certified, deinked, processed chlorine-free, and manufactured with renewable biogas energy. It is acid-free and EcoLogo certified. 
For whom I love the most

Anneliese and Grace-the reason

Evelyn, Bob, and Lance-the source 
This page intentionally left blank 